Amalia, L. · R. Budiasih · A. Samsul

\title{
Pengaruh posisi bukaan plastik baglog dan konsentrasi pupuk fosfor terhadap pertumbuhan dan hasil jamur tiram putih (Pleurotus ostreatus)
}

Diterima : 13 Februari 2018/Disetujui : 13 Maret 2018 / Dipublikasikan : 31 Maret 2018

CDepartment of Crop Science, Padjadjaran University

\begin{abstract}
The decrease in mushroom productivity due to openings at the top of the baglog needs to be balanced with phosphor to increase the mushroom harvest. The research study the interaction effect of opening position plastic baglogs and concentration of phosphor fertilizers to growth and yield of oyster mushroom. The experiment has been done in Mushrooms House, Faculty of Agriculture, Winaya Mukti University, Sumedang with altitude of $850 \mathrm{~m}$ above sea level. It was carried out from September until December 2015. The experimental design used in this experiment was completely randomized design and treatment design was factorial. The treatment consisted of two factors: the opening position of plastic baglogs and fertilizer concentrations of phosphor fertilizer. Opening position of plastic baglogs consists of a 6 levels that $b_{1}=$ vertically baglog, the top of baglog opened entirely, $b_{2}=$ vertically baglog, left side baglog opened at areas $3 \mathrm{~cm} \times 1 \mathrm{~cm}, b_{3}=$ vertically baglog, left and right side baglog opened at areas $3 \mathrm{~cm} \times 1 \mathrm{~cm}, \mathrm{~b}_{4}$ $=$ horizontally baglog, left and right side baglog opened entirely, $b_{5}=$ the left side baglog opened at areas $3 \mathrm{~cm} \times 1 \mathrm{~cm}$, and $b_{6}=$ left and right side baglog opened at areas $3 \mathrm{~cm} \times 1 \mathrm{~cm}$. The concentration of phosphor fertilizer consisted of 3 levels that $\mathrm{p}_{0}=0 \mathrm{~g} \mathrm{~L}^{-1}$ solution, $\mathrm{p}_{1}$ $=0.25 \mathrm{~g} \mathrm{~L}^{-1}$ solution, and $\mathrm{p}_{2}=0.50 \mathrm{~g} \mathrm{~L}^{-1}$ solution. All treatment was replicated 2 times. The results showed that there was interaction between opening position of plastic baglog and a concentration of phosphor fertilizer to height of mushroom fruiting bodies.
\end{abstract}

Keywords: Baglog, Oyster Mushrooms, Phosphor
Sari. Penurunan produktivitas jamur akibat bukaan plastik pada bagian atas baglog perlu diimbangi dengan pemberian fosfor untuk meningkatkan hasil panen jamur tiram. Penelitian bertujuan untuk mempelajari pengaruh interaksi posisi bukaan plastik baglog dan konsentrasi pupuk fosfor terhadap pertumbuhan dan hasil jamur tiram putih. Percobaan telah dilakukan di Kumbung Jamur Fakultas Pertanian Universitas Winaya Mukti (UNWIM), Kabupaten Sumedang dengan ketinggian tempat $850 \mathrm{~m}$ di atas permukaan laut dan dilaksanakan mulai dari bulan September sampai bulan Desember 2015. Rancangan percobaan yang digunakan adalah Rancangan Acak Lengkap dengan rancangan perlakuan adalah faktorial. Perlakuan terdiri dari dua faktor yaitu posisi bukaan plastik baglog dan konsentrasi pupuk fosfor. Posisi bukaan plastik baglog terdiri dari 6 taraf faktor yaitu $b_{1}=$ baglog diberdirikan, bagian atas baglog dibuka seluruhnya, $\mathrm{b}_{2}=$ baglog diberdirikan, samping kiri baglog bagian tengahnya dibuka seluas $3 \mathrm{~cm} \times 1 \mathrm{~cm}$, $\mathrm{b}_{3}=$ baglog diberdirikan, samping kiri dan kanan baglog bagian tengahnya dibuka seluas $3 \mathrm{~cm} \times 1 \mathrm{~cm}$, $\mathrm{b}_{4}=$ baglog ditidurkan, samping kiri dan kanan baglog dibuka seluruhnya, $\mathrm{b}_{5}=$ baglog ditidurkan, samping kiri baglog bagian tengahnya dibuka seluas $3 \mathrm{~cm} \times 1 \mathrm{~cm}$, dan $\mathrm{b}_{6}=$ baglog ditidurkan, samping kiri dan kanan baglog bagian tengahnya dibuka seluas $3 \mathrm{~cm} \times 1 \mathrm{~cm}$. Konsentrasi pupuk fosfor terdiri dari 3 taraf faktor yaitu $\mathrm{p}_{0}=0 \mathrm{~g} \mathrm{~L}^{-1}$ Larutan, $\mathrm{p}_{1}=0,25 \mathrm{~g} \mathrm{~L}^{-1}$ Larutan , dan $\mathrm{p}_{2}=0,50 \mathrm{~g} \mathrm{~L}^{-1}$ Larutan, sehingga terdiri dari 18 kombinasi perlakuan yang diulang sebanyak 2 kali. Hasil percobaan menunjukkan terjadi interaksi antara posisi bukaan plastik baglog dengan konsentrasi pupuk fosfor terhadap tinggi tubuh buah jamur.

Kata kunci : Baglog, Fosfor, Jamur Tiram

Dikomunikasikan oleh Syariful Mubarok

Amalia, L. · R. Budiasih · A. Samsul

Fakultas Pertanian Universitas Winaya Mukti

Koresspondensi : lia8264@yahoo.com

Amalia, L. dkk. : Pengaruh posisi bukaan plastik baglog dan konsentrasi pupuk SP-36 terhadap pertumbuhan dan hasil jamur tiram putih (Pleurotus ostreatus) 


\section{Pendahuluan}

Jamur tiram merupakan tanaman heterotrofik karena hidupnya dengan cara mengambil zatzat makanan seperti selulosa, glukosa, lignin, protein, dan senyawa pati dari organisme lain. Jamur tiram mengandung karbohidrat $(50,59 \%)$, serat $(1,56 \%)$, lemak $(0,17 \%)$ dan abu $1,14 \%$. Selain kandungan ini, setiap $100 \mathrm{~g}$ jamur tiram segar ternyata juga mengandung 45,65 kalori, 8,9 mg kalsium, 17,0 mg fosfor, $1,9 \mathrm{mg}$ besi, $0,15 \mathrm{mg}$ vitamin $B_{1}, 0,75 \mathrm{mg}$ vitamin $B_{2}$ dan $12,40 \mathrm{mg}$ vitamin C. Kandungan protein (10,5\%-30,4\%) yang terdapat pada jamur lebih tinggi dibandingkan dengan bahan makanan lain yang juga berasal dari tanaman, yakni protein jamur dua kali lebih tinggi daripada asparagus dan kentang, empat kali lebih tinggi daripada wortel dan tomat serta enam kali lebih tinggi dari pada jeruk (Cahyana dkk., 2004).

Jamur akan keluar dari baglog setelah 100\% miselium memenuhi baglog (sekitar 40 hari setelah pembenihan). Petani jamur tiram umumnya hanya mengandalkan satu bukaan pada bagian atas baglog dengan cara melepas tutup kapasnya dan dilanjutkan dengan memotong bagian atas baglog. Kegiatan tersebut berakibat terhadap penurunan produktivitas baglog karena media akan cepat kering sehingga jamur sukar untuk tumbuh lebih banyak meskipun areal permukaan baglog dipotong. Oleh karena itu perlu dicoba beberapa posisi bukaan plastik baglog untuk meningkatkan produktivitas jamur tanpa menimbulkan kekeringan pada media di dalam baglog yaitu dengan cara membuat lubang sobekan di berbagai tempat (bagian atas, samping, dan tengah). Keunggulan jenis bukaan baglog pada teknik pembukaan kapas dan sayatan plastik, panen cenderung stabil, pertumbuhan bisa merata di seluruh permukaan jamur baik di depan maupun belakang, penyiramannya pun mudah, hanya dengan spoiler halus saja air bisa masuk ke permukaan jamur dengan stabil. Adapun kelemahannya adalah cenderung mudah kering dan kisut karena baglog akan mengalami penguapan akibat banyaknya udara yang masuk melalui lubang sayatan. Untuk melengkapi keunggulan dan kelemahan dari macam-macam bukaan maka perlu dilakukan penelitian.

Petani biasanya menambahkan pupuk tambahan dengan cara disemprotkan ke dalam baglog untuk meningkatkan hasil panen jamur tiram, antara lain dengan pemberian pupuk fosfor. Menurut Wahyudin dkk. (2017), pupuk fosfor yang diberikan bersama-sama dengan pupuk N, K, dan Guano anatara lain berpengaruh terhadap tinggi tanaman, bobot kering tanaman, biomassa tanaman, indeks panen kedelai varietas Willis. Selanjutnya Ruminta dkk. (2017) juga menyebutkan bahwa penggunaan pupuk fosfor bersama-sama pupuk $\mathrm{N}$, dan $K$, berpengaruh terhadap rendemen kerontokan tanaman sorghum. Fosfor berperan dalam penyusunan asam nukleat, fosfolipid, koenzim, NAD dan NADP dan sebagai unsur utama dari ATP. Fosfor selain dapat merangsang tumbuhnya tunas juga dapat memperkuat tanaman terhadap serangan hama. Tujuan dari penelitian ini untuk mempelajari pengaruh interaksi posisi bukaan plastik baglog dan konsentrasi pupuk fosfor terhadap pertumbuhan dan hasil jamur tiram putih.

\section{Bahan dan Metode}

Penelitian ini dilaksanakan di Kumbung Jamur Fakultas Pertanian UNWIM, Kabupaten Sumedang dengan ketinggian tempat $850 \mathrm{~m}$ di atas permukaan laut dan dilaksanakan dari September sampai Desember 2015.

Bahan yang digunakan antara lain baglog jamur tiram dengan miselium $80 \%$, pupuk fosfor (SP36), air dan alat yang digunakan antara lain rak bambu, hand sprayer, pisau, timbangan, gelas ukur dan alat tulis.

Alat-alat yang digunakan dalam percobaan ini adalah rak kayu, sprayer, timbangan, penggaris, timbangan elektrik, jangka sorong, dan alat-alat tulis.

Rancangan perlakuan yang digunakan adalah Rancangan Acak Lengkap dengan rancangan perlakuan faktorial. Percobaan terdiri dari dua faktor perlakuan yaitu macam bukaan plastik baglog yang terdiri dari 6 taraf dan konsentrasi pupuk fosfor yang terdiri dari 3 taraf, sehingga terdiri dari 18 perlakuan yang diulang sebanyak 2 kali. Setiap perlakuan terdiri dari 10 baglog, sehingga jumlah baglog secara keseluruhan adalah 360 baglog. Sampel untuk masing-masing perlakuan adalah 4 baglog.

Adapun taraf faktor macam bukaan plastik baglog adalah:

$\mathrm{b}_{1}=$ baglog diberdirikan, bagian atas baglog dibuka seluruhnya

$\mathrm{b}_{2}=$ baglog diberdirikan, samping kiri 
baglog bagian tengahnya dibuka seluas $3 \mathrm{~cm} \times 1 \mathrm{~cm}$

$\mathrm{b}_{3}=$ baglog diberdirikan, samping kiri dan kanan baglog bagian tengahnya dibuka seluas $3 \mathrm{~cm} \times 1 \mathrm{~cm}$

$\mathrm{b}_{4}=$ baglog ditidurkan, samping kiri dan kanan baglog dibuka seluruhnya

$\mathrm{b}_{5}=$ baglog ditidurkan, samping kiri baglog bagian tengahnya dibuka seluas $3 \mathrm{~cm} \mathrm{x}$ $1 \mathrm{~cm}$

$\mathrm{b}_{6}=$ baglog ditidurkan, samping kiri dan kanan baglog bagian tengahnya dibuka seluas $3 \mathrm{~cm} \times 1 \mathrm{~cm}$

Taraf konsentrasi Pupuk SP-36 adalah :

$$
\begin{aligned}
& \mathrm{p}_{0}=0 \mathrm{~g} \mathrm{~L}^{-1} \\
& \mathrm{p}_{1}=0,25 \mathrm{~g} \mathrm{~L}^{-1} \\
& \mathrm{p}_{2}=0,50 \mathrm{~g} \mathrm{~L}^{-1}
\end{aligned}
$$

Pengamatan utama yang diamati antara lain :

1. Jumlah Tubuh Buah Jamur Tiram per baglog (buah), yaitu rata-rata jumlah tubuh buah jamur tiram sampel yang dihitung pada saat panen.

2. Tinggi Tanaman $(\mathrm{cm})$, yaitu rata-rata tinggi jamur tiram sampel yang dihitung pada saat panen.

3. Diameter Batang ( $\mathrm{mm})$, yaitu rata-rata diameter batang jamur tiram sampel pada saat panen.

4. Diameter Tudung (cm), yaitu rata-rata diameter tudung jamur tiram sampel yang dihitung pada saat panen.

5. Bobot Buah Jamur (g), yaitu rata-rata bobot buah jamur tiram sampel yang dipanen pada setiap baglog. Bobot buah jamur ini diukur pada saat setelah panen (bobot segar), pada saat 4 jam setelah panen dan pada saat 8 jam setelah panen.

Bila $F_{\text {hit }}$ perlakuan lebih besar dari $F_{\text {tab }}$ pada taraf nyata 0.05 berarti terdapat keragaman pada perlakuan, selanjutnya dilakukan pengujian dengan uji beda rata-rata. Uji beda rata-rata perlakuan yang digunakan adalah uji jarak berganda Duncan pada taraf nyata 0.05 .

\section{Hasil dan Pembahasan}

Jumlah Tubuh Buah Jamur per baglog. Hasil pengamatan dan analisis statistik jumlah tubuh buah jamur disajikan pada Tabel 1 .

Jamur tiram merupakan tanaman heterotropik yang mana hidupnya tergantung pada kondisi lingkungan tempat tumbuh. Faktor lingkungan yang mempengaruhi pertumbuhan jamur adalah air, keasaman $(\mathrm{pH})$, substrat, kelembaban, suhu dan ketersediaan nutrisi. Selain itu juga jamur tiram merupakan tanaman makroskopik yang tidak memiliki klorofil. Jamur sebagai tanaman yang memiliki spora dan merupakan sel-sel lepas yang bersambungan membentuk benang bersekat dan disebut hifa. Hifa jamur terdiri atas sel-sel yang berinti satu. Hifa jamur menyatu membentuk jaringan yang disebut miselium. Miselium bercabang dan pada titik pertemuannya membentuk bintik kecil yang disebut sporangium yang akan berkembang menjadi pin head / calon tubuh buah jamur (Djarijah, 2001 dan Unus Suriawiria, 2002).

Tabel 1. Pengaruh Posisi Bukaan Plastik Baglog dan Konsentrasi Pupuk fosfor terhadap Jumlah Tubuh Buah Jamur per baglog

\begin{tabular}{cc}
\hline Perlakuan & $\begin{array}{c}\text { Rata-rata Jumlah } \\
\text { Tubuh Buah Jamur }\end{array}$ \\
\hline Posisi Baglog (B) : & \\
\hline $\mathrm{b}_{1}$ & $3,15 \mathrm{a}$ \\
$\mathrm{b}_{2}$ & $3,15 \mathrm{a}$ \\
$\mathrm{b}_{3}$ & $3,12 \mathrm{a}$ \\
$\mathrm{b}_{4}$ & $2,93 \mathrm{a}$ \\
$\mathrm{b}_{5}$ & $3,27 \mathrm{a}$ \\
$\mathrm{b}_{6}$ & $2,99 \mathrm{a}$ \\
\hline Konsentrasi Pupuk Fosfor (P) : & \\
\hline $\mathrm{p}_{0}$ & $3,14 \mathrm{a}$ \\
$\mathrm{p}_{1}$ & $2,98 \mathrm{a}$ \\
$\mathrm{p}_{2}$ & $3,18 \mathrm{a}$ \\
\hline
\end{tabular}

Keterangan : Angka rata-rata yang diikuti huruf kecil (arah vertikal) yang sama, tidak nyata menurut Uji Jarak Berganda Duncan pada taraf nyata $5 \%$

Idealnya Unsur hara yang dibutuhkan miselium jamur, yaitu N, P, K, C, S, Mg, Fe, Zn, Mn, Mo, dan vitamin B (B1, B3, B7). Nutrisi tersebut diperlukan untuk berbagai proses metabolisme sel dalam rangka menghasilkan energi tinggi ATP untuk tumbuh (Garcha dkk. 1981).

Tinggi Tubuh Buah (cm). Hasil pengamatan dan analisis statistik tinggi tubuh buah disajikan pada Tabel 2.

Dari Tabel 2 terlihat bahwa terjadi interaksi antara posisi bukaan plastik baglog dengan konsentrasi pupuk fosfor terhadap tinggi tubuh buah jamur. Pada posisi bukaan plastik baglog $b_{1}$, perlakuan $\mathrm{p}_{0}$ berbeda tidak nyata dengan perlakuan konsentrasi pemupukan fosfor 
lainnya terhadap karakter tubuh buah jamur. Pada posisi bukaan plastik baglog $\mathrm{b}_{2}$, perlakuan $\mathrm{p}_{0}$ memberikan pengaruh lebih tinggi untuk karakter tinggi tubuh buah dan berbeda nyata dengan perlakuan lainnya. Pada posisi bukaan plastik baglog $b_{3}$ dan $b_{4}$, semua perlakuan konsentrasi pupuk fosfor berbeda tidak nyata satu sama lain. Pada posisi bukaan plastik baglog $b_{5}$, perlakuan $p_{0}$ berbeda nyata dengan perlakuan $\mathrm{p}_{1}$, tetapi berbeda tidak nyata dengan perlakuan $\mathrm{p}_{2}$. Pada posisi bukaan plastik baglog $\mathrm{b}_{6}$, perlakuan $\mathrm{p}_{0}$ berbeda tidaknyata dengan perlakuan $p_{1}$ tapi berbeda nyata dengan $p_{2}$. Pada konsentrasi pupuk fosfor $\left(0 \mathrm{~g} \mathrm{~L}^{-1}\right)$, perlakuan posisi bukaan plastik $b_{1}$ berbeda nyata dengan $\mathrm{b}_{3}$, tapi berbeda tidak nyata dengan perlakuan lainnya. Pada konsentrasi pupuk fosfor $(0,25 \mathrm{~g} \mathrm{~L}-$ 1), perlakuan posisi bukaan plastik $b_{1}$ berbeda nyata dengan perlakuan $b_{2}, b_{3}$ dan $b_{5}$, tetapi berbeda tidak nyata dengan perlakuan lainnya. Pada konsentrasi pupuk fosfor $\left(0,50 \mathrm{~g} \mathrm{~L}^{-1}\right)$, perlakuan posisi bukaan plastik b1 berbeda tidak nyata dengan perlakuan lainnya.

Tabel 2. Pengaruh Posisi Bukaan Plastik Baglog dan Konsentrasi Pupuk SP-36 terhadap Tinggi Tubuh Buah Jamur

\begin{tabular}{ccccccc}
\hline $\mathrm{P} / \mathrm{B}$ & $\mathrm{b}_{1}$ & $\mathrm{~b}_{2}$ & $\mathrm{~b}_{3}$ & $\mathrm{~b}_{4}$ & $\mathrm{~b}_{5}$ & $\mathrm{~b}_{6}$ \\
\hline $\mathrm{p}_{0}$ & $5,45 \mathrm{ab}$ & $4,95 \mathrm{~b}$ & $4,15 \mathrm{a}$ & $4,65 \mathrm{a}$ & $5,25 \mathrm{~b}$ & $5,25 \mathrm{~b}$ \\
& $\mathrm{~B}$ & $\mathrm{AB}$ & $\mathrm{A}$ & $\mathrm{AB}$ & $\mathrm{AB}$ & $\mathrm{AB}$ \\
$\mathrm{p}_{1}$ & $5,90 \mathrm{~b}$ & $3,75 \mathrm{a}$ & $4,05 \mathrm{a}$ & $4,95 \mathrm{a}$ & $3,75 \mathrm{a}$ & $5,65 \mathrm{~b}$ \\
& $\mathrm{C}$ & $\mathrm{A}$ & $\mathrm{AB}$ & $\mathrm{BC}$ & $\mathrm{A}$ & $\mathrm{C}$ \\
$\mathrm{p}_{2}$ & $4,70 \mathrm{a}$ & $3,70 \mathrm{a}$ & $3,65 \mathrm{a}$ & $5,40 \mathrm{a}$ & $4,85 \mathrm{~b}$ & $3,85 \mathrm{a}$ \\
& $\mathrm{ABC}$ & $\mathrm{AB}$ & $\mathrm{A}$ & $\mathrm{C}$ & $\mathrm{BC}$ & $\mathrm{AB}$ \\
\hline
\end{tabular}

Keterangan : Angka rata-rata yang diikuti huruf kecil (arah vertikal) dan huruf kapital (arah horizontal) yang sama, tidak nyata menurut Uji Jarak Berganda Duncan pada taraf nyata 5\%

Menurut Dwijoseputro (1988), unsur fosfor merupakan unsur esensial dari gula fosfat yang berperan dalam nukleotida, seperti RNA dan DNA, serta sebagian dari fosfolipid pada membran sel. Fosfor berperan pula dalam metabolism energi karena keberadaannya dalam ATP, ADP dan AMP.

Diameter Tudung Buah $(\mathrm{cm})$ dan Diameter Batang $(\mathbf{m m})$. Hasil pengamatan dan analisis statistik diameter tudung buah dan diameter batang disajikan pada Tabel 3.

Berdasarkan Tabel 3, tidak terjadi interaksi antara perlakuan posisi bukaan plastik baglog dan konsentrasi pupuk fosfor terhadap diameter batang dan diameter tudung buah jamur. Perlakuan posisi bukaan plastik baglog $\mathrm{b}_{4}$ berbeda nyata dengan perlakuan $b_{5}$ tapi berbeda tidak nyata dengan perlakuan lainnya terhadap diameter batang; perlakuan $b_{5}$ berbeda nyata dengan perlakuan $b_{3}$ dan $b_{4}$ terhadap diameter tudung buah jamur.

Tabel 3. Pengaruh Posisi Bukaan Plastik Baglog dan Konsentrasi Pupuk Fosfor terhadap Diameter Batang dan Diameter Tudung Buah

\begin{tabular}{ccl}
\hline Perlakuan & \multicolumn{2}{l}{ Rata-rata } \\
\cline { 2 - 3 } & $\begin{array}{l}\text { Diameter } \\
\text { Batang }(\mathbf{m m})\end{array}$ & $\begin{array}{l}\text { Diameter } \\
\text { Tudung } \\
\text { Buah } \mathbf{( c m})\end{array}$ \\
\hline Posisi Baglog (B) & $10,18 \mathrm{ab}$ & $9,97 \mathrm{ab}$ \\
$\mathrm{b}_{1}$ & $11,02 \mathrm{ab}$ & $9,80 \mathrm{ab}$ \\
$\mathrm{b}_{2}$ & $10,18 \mathrm{ab}$ & $9,15 \mathrm{a}$ \\
$\mathrm{b}_{3}$ & $9,28 \mathrm{a}$ & $9,27 \mathrm{a}$ \\
$\mathrm{b}_{4}$ & $11,83 \mathrm{~b}$ & $10,50 \mathrm{~b}$ \\
$\mathrm{~b}_{5}$ & $10,92 \mathrm{ab}$ & $9,87 \mathrm{ab}$ \\
$\mathrm{b}_{6}$ & $10,77 \mathrm{a}$ & $9,81 \mathrm{a}$ \\
Konsentrasi Pupuk Fosfor $\mathbf{( P )}$ & $9,63 \mathrm{a}$ \\
$\mathrm{p}_{0}$ & $10,38 \mathrm{a}$ & $9,84 \mathrm{a}$ \\
$\mathrm{p}_{1}$ & $10,57 \mathrm{a}$ & \\
$\mathrm{p}_{2}$ &
\end{tabular}

Keterangan : Angka rata-rata yang diikuti huruf kecil (arah vertikal) yang sama, tidak nyata menurut Uji Jarak Berganda Duncan pada taraf nyata 5\%

Perlakuan konsentrasi pupuk fosfor berbeda tidak nyata satu dengan lainnya terhadap diameter batang dan diameter tudung buah jamur. Hal ini senada dengan hasil penelitian Nurul Hariadi dkk., (2013), bahwa hal ini disebabkan salah satunya karena terjadinya pengempisan permukaan baglog yang berakibat terbentuknya rongga. Rongga tersebut mengakibatkan pembentukan badan buah ganda. Hal ini berpengaruh terhadap penyerapan nutrisi. Suplai makanan (Fosfor) yang kurang mencukup menyebabkan tubuh buah jamur tiram putih kecil-kecil. Semakin banyak jumlah tubuh buah jamur yang terbentuk, menyebabkan diameter batang dan diameter tudung buah jamur semakin kecil.

Menurut Chang dan Miles (1989) dalam tubuh buah jamur, air merupakan komponen terbesar yaitu 85\%-95\%. Peningkatan diameter tudung buah jamur menyebabkan kandungan air yang dimiliki makin banyak.

Bobot Segar Buah Jamur (g). Hasil pengamatan dan analisis statistik bobot buah jamur disajikan pada Tabel 4.

Berdasarkan Tabel 4, tidak terjadi interaksi antara perlakuan posisi bukaan plastik baglog dan konsentrasi pupuk fosfor terhadap bobot segar, bobot setelah disimpan 4 jam dan bobot 
setelah disimpan 8 jam. Posisi bukaan plastik baglog dan konsentrasi pupuk fosfor berpengaruh tidak nyata satu sama lainnya. Hal ini berbeda dengan hasil penelitian Mahdi Fauzi, dkk., (2013) yang menyatakan bahwa pemberian pupuk fosfor berpengaruh nyata terhadap diameter batang, diameter tubuh buah jamur dan bobot segar jamur. Perbedaan tersebut dimungkinkan karena pemberian konsentrasi fosfor yang kurang tepat atau kurang memenuhi untuk meningkatkan aktivitas fisiologi jamur dalam merubah senyawa kompleks seperti selulose, protein, lignin, dan senyawa pati yang akan diuraikan dengan bantuan enzim menjadi senyawa yang lebih sederhana seperti glukosa, yang akan diproses dalam respirasi jamur melalui proses glikolisis, siklus krebs, dan reaksi lain guna menghasilkan senyawa organik dan energi yang dibutuhkan untuk pertumbuhan dan perkembangan sel-sel jamur.

Tabel 4. Pengaruh Posisi Bukaan Plastik Baglog dan Konsentrasi Pupuk Fosfor terhadap Bobot Segar Buah Jamur

\begin{tabular}{|c|c|c|c|}
\hline \multirow[t]{2}{*}{ Perlakuan } & \multicolumn{3}{|l|}{ Rata-rata } \\
\hline & $\begin{array}{l}\text { Bobot } \\
\text { Segar }(\mathrm{g})\end{array}$ & $\begin{array}{l}\text { Bobot } \\
\text { Setelah } \\
\text { disimpan } 4 \\
\text { Jam (g) }\end{array}$ & $\begin{array}{l}\text { Bobot } \\
\text { Setelah } \\
\text { disimpan } 8 \\
\text { Jam }(g)\end{array}$ \\
\hline \multicolumn{4}{|c|}{ Posisi Baglog (B) : } \\
\hline$b_{1}$ & 98,89 a & 97,15 a & 92,22 a \\
\hline $\mathrm{b}_{2}$ & 113,26 a & 108,26 a & 139,93 a \\
\hline$b_{3}$ & 90,56 a & 88,33 a & 84,72 a \\
\hline $\mathrm{b}_{4}$ & 90,49 a & 87,78 a & 84,24 a \\
\hline$b_{5}$ & 106,74 a & 104,10 a & 98,82 a \\
\hline $\mathrm{b}_{6}$ & 90,49 a & 88,20 a & 81,88 a \\
\hline \multicolumn{4}{|c|}{ Konsentrasi Pupuk Fosfor (P) : } \\
\hline $\mathrm{p}_{0}$ & 107,40 a & 103,44 a & 99,48 a \\
\hline $\mathrm{p}_{1}$ & 86,32 a & 83,96 a & 79,83 a \\
\hline $\mathrm{p}_{2}$ & 101,49 a & 99,52 a & $111,60 \mathrm{a}$ \\
\hline
\end{tabular}

Keterangan : Angka rata-rata yang diikuti huruf kecil (arah vertikal) yang sama, tidak nyata menurut Uji Jarak Berganda Duncan pada taraf nyata 5\%

\section{Kesimpulan}

Terjadi interaksi antara posisi bukaan plastik baglog dengan konsentrasi pupuk fosfor terhadap tinggi tubuh buah jamur, namun tidak terjadi interaksi antara posisi bukaan plastik baglog dengan konsentrasi pupuk fosfor terhadap jumlah tubuh buah jamur, diameter tubuh buah, diameter batang dan bobot buah jamur.

\section{Daftar Pustaka}

Agus Wahyudin, Fikry Yulianto Wicaksono, Aep Wawan Irwan, Ruminta Ruminta, Rizka Fitriani. 2017. Respon Tanaman Kedelai (Glicine max) Varietas Wilis akibat Pemberian Berbagai Dosis pupuk N, P, K dan Pupuk Guano pada Tanah Inceptisol Jatinangor. Kultivasi Vol 16, No. 2 (2017).

Cahyana, Muchroji, dan Bachrun. 2004. Jamur Tiram. Penebar Swadaya, Jakarta.

Chang, S.T. dan W.A. Miles. 1989. Tropical Mushrooms Biobaglogical Nature and Cultivation Method. The Chinese Press. Hongkong.

Djarijah. 2001. Budidaya Jamur Tiram. Kanisius. Jakarta. pp.67

Dwijoseputro. 1988. Fisiobaglogi Tumbuhan. PT. Gramedia. Jakarta.

Garcha, H., S. Amarjit, and R. Phutela. 1981. Utilization of agricultural waste for mushroom cultivation in India. Mushroom Sci. 11(1):245-256.

Mahdi Fauzi, T. Chairun Nisa dan Syukri. 2013. Pengaruh Tiga Media Tanam Serbuk Kayu dan Pemberian Pupuk pada Produksi Jamur Tiram Putih (Pleurotus ostreatus (var.) Florida). Journal on line Agroekoteknologi 1(2). ISSN No. 2337-6597.

Nurul Hariadi, Lilik Setyobudi, Ellis Nihayati. 2013. Studi Pertumbuhan dan Hasil Produksi Jamur Tiram Putih (Pleurotus ostrea-tus) pada Media Tumbuh Jerami Padi dan Serbuk Gergaji. J. Produksi Tanaman 1(1) : 47-53.

Ruminta R., Agus Wahyudin, Muhammad Lukman Hanifa. 2017. Pengaruh NPK dan Pupuk Organik Kelinci terhadap Hasil Sorgum (Sorghum bicolor (Linn) Moench) di Lahan Tadah Hujan Jatinangor. Kultivasi Vol 16, No. 2 (2017).

Unus Suriawiria. 2002. Budidaya Jamur Tiram. Kanisius, Jakarta. 